\title{
PENERAPAN ALGORITMA C4.5 UNTUK PENENTUAN KELAYAKAN PEMBERIAN KREDIT (Studi Kasus : Koperia - Koperasi Warga Komplek Gandaria)
}

\section{Implementation of C4.5 Algorithm To Determine The Feasibility of Loan (Case Study: Koperia - Koperasi Warga Komplek Gandaria)}

\author{
Teguh Budi Santoso, teguh.santos12@gmail.com ${ }^{1)}$, Dela Sekardiana, \\ dellasekar23@gmail.com ${ }^{2)}$ \\ 1)2) 1)Teknik Informatika/Fakultas Teknik, Universitas Satya Negara Indonesia
}

\begin{abstract}
Current credit giving in KOPERIA (Koperasi Warga Komplek Gandaria) is still based on an objective process. Difficulties in determining the feasibility of giving credit are often experienced by cooperative managers, so that problems arise in the cooperative is a default payment of credit installments of customers in KOPERIA. This study aims to form a decision tree classification model to determine the customer's credit worthiness. In this study the application of C4.5 Algorithm, based on the Sets and Attributes used in this study, namely, the amount of income divided into 2 categories $>5$ million and 3-5 million, the amount of balance divided into three, namely> 3 million, 1-3 million and <1 Million, The Loan Amount is divided into three, namely 1-4 Months, 5-8 months, and 9-12 Months and Requirements with attributes of Business Capital, buying goods and others. In this study determine the appropriate root nodes, the classification results using C4.5 Algorithm shows that the accuracy of 97.5\% is obtained, based on the results obtained shows that the c4.5 algorithm is suitable to be used to determine the feasibility of lending customers to KOPERIA.
\end{abstract}

Keywords: Data Mining, C4.5 Algorithm, loan feasibility

\begin{abstract}
ABSTRAK
Pemberikan kredit saat ini yang terjadi di KOPERIA (Koperasi Warga Komplek Gandaria) kepada nasabah masih berdasarkan proses yang tidak obyektif. Kesulitan dalam menentukan kelayakan pemberian kredit yang sering dialami oleh pengurus koperasi, sehingga muncul masalah pada koperasi adalah macetnya pembayaran angsuran kredit nasabah pada KOPERIA. Penelitian ini bertujuan membentuk model klasifikasi pohon keputusan untuk menentukan kelayakan kredit nasabah. Pada penelitian ini penerapan Algoritma C4.5, berdasarkan Himpunan dan Atribut yang digunakan pada penelitian ini yaitu, Jumlah Penghasilan dibagi menjadi 2 kategori $>5$ Juta dan 3-5Juta, Jumlah Saldo dibagi menjadi tiga yaitu >3 Juta, 1-3 Juta dan < 1Juta, Jumlah Pinjaman dibagi menjadi tiga yaitu 1-4 Bulan, 5-8 bulan, dan 9 -12 Bulan dan Keperluan dengan attribute Modal Usaha, membeli barang dan lain-lain. Pada Penelitian ini menentukan node akar yang sesuai, hasil klasifikasi menggunakan Algoritma C4.5 menunjukan bahwa diperoleh akurasi $97,5 \%$, berdasarkan hasil yang diperoleh menunjukan bahwa algoritma c4.5 cocok digunakan untuk menentukan kelayakan pemberian kredit nasabah pada KOPERIA. Kata Kunci: Data Mining, Algoritma C4.5, kelayakan kredit
\end{abstract}

\section{PENDAHULUAN}

Koperia adalah sebuah badan usaha yang bergerak dibidang simpan pinjam uang untuk memenuhi kebutuhan masyarakat dalam hal keuangan. Dapat diketahui bahwa di koperia sudah banyak yang melakukan transaksi kredit akan tetapi pengurus koperia pada saat ini untuk memberikan kredit kepada nasabah masih berdasarkan proses yang tidak obyektif. Oleh sebab itu sulit menentukan kelayakan pemberian kredit yang sering dialami oleh pengurus koperia. Adapun masalah yang 
muncul pada koperia adalah pembayaran angsuran. Seseorang yang sering menunggak dikarenakan penghasilan mereka yang kurang mencukupi. Dimana jika banyak nasabah yang menunggak dalam pembayaran maka akan mengganggu sistem keuangan perusahaan.

Untuk penentuan kelayakan pemberian kredit bisa dilakukan dengan proses perhitungan yang tepat (Firmansyah,2011), dengan menggunakan algoritma C4.5, dapat menentukan model pohon keputusan (Teguh Budi Santoso,2014) untuk meningkatkan akurasi dalam menganalisa kelayakan kredit yang diajukan calon debitur, Dalam metode ini diharapkan akan mampu untuk menentukan pemberian kredit yang layak atau tidak layak kepada nasabah. Dengan menerapkan beberapa atribut yang mampu mengurangi tingkat resiko penunggakan. Adapun atribut yang digunakan yaitu jumlah penghasilan, jumlah saldo, jumlah pinjaman, jangka waktu dan keperluan. Penelitian ini bertujuan untuk penentuan kelayakan pemberian kredit kepada nasabah, sehingga pihak koperasi dapat membantu menyelesaikan penentuan kelayakan pemberian kredit.

Permasalahan yang muncul berdasrkan uraian diatas adalah masih terjadinya proses yang sifatnya objektif dalam penentuan kelayakan kredit, yang menyebabkan tidak akuratnya data, seperti pengajuan kredit yang bermasalah dalam pembayaran angsuran kredit.

Dengan menerapkan algoritma C4.5 diharapkan dapat meningkatkan keakuratan analisa kredit, dalam penentuan kelayakan kredit.

\section{METODOLOGI PENELITIAN}

Pada penelitian ini data yang digunakan adalah data sekunder atau data yang berasal dari jurnal, paper, buku serta beberapa informasi lainnya yang berhubungan dengan penelitian yang dikutip.

Pengolahan data yang dibutuhkan dimulai dengan menentukan pengelompokan data dengan menentukan himpunan dan atribut, berdasarkan data pada KOPERIA.

\section{Tabel 1. Himpunan Atribut}

\begin{tabular}{|l|l|}
\hline Atribut & \\
\hline Total kasus & Kategori \\
\hline & \\
\hline Jumlah Penghasilan & $>$ 5 Juta \\
\hline & 3-5 Juta \\
\hline Jumlah Saldo & > 3 Juta \\
\hline & 1-3 Juta \\
\hline & $<$ Juta \\
\hline Jumlah Pinjaman & 11-20 Juta \\
\hline & 6-10 Juta \\
\hline & 1-5 Juta \\
\hline Jangka Waktu & 1-4 Bulan \\
\hline & 5-8 Bulan \\
\hline & 9-12 Bulan \\
\hline Keperluan & Modal Usaha \\
\hline & Membeli Barang \\
\hline & Lain-lain \\
\hline & \\
\hline
\end{tabular}

Table 2 data training Set Nasabah

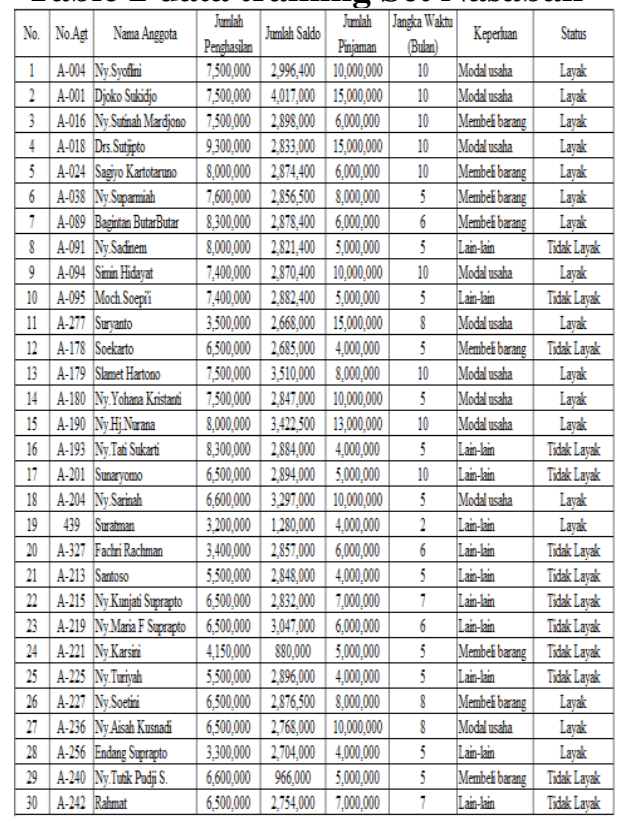

Guna tercapainya akurasi untuk menentukan kelayakan kredit maka metode yang dipakai adalah Algoritma C4.5, sesuai dengan penelitian yang sudah dilakukan sebelumnya.

Evaluasi dan validasi hasil dalam penelitian ini adalah klasifikasi pada data training berdasarkan waktu dan proses yang dibutuhkan, tingkat akurasi serta jumlah data yang diklasifikasikan kedalam kelas YA/TIDAK. Untuk mengetahui evaluasi 
dari kinerja model klasifikasi didasarkan pada banyaknya (count) ditabulasikan dalam sebuah hasil yang dikenal sebagai confusion matrix. (CRISP-DM) (Larose, 205) terdiri dari tahap antara lain:

1. business understading, data understanding, data yang diambil berdasarkan laporan kredit tahun 2015 sebanyak 30 nasabah, berdasarkan jumlah penghasilan, jumlah saldo, jumlah pinjaman, jangka waktu dan keperluan. Berikut nama atribut, kategori, dan nilai (rangeny). Berikut rulenya nilainya:

\section{Tahapan data prepetion}

Pada table 2 menunjukan data training set data nasabah:

\section{HASIL DAN PEMBAHASAN}

Tujuan dari penelitian ini menguji keakuratan analisa kredit, untuk kelayakan pengajuan kredit dengan menggunakan algoritma C4.5. data yang dianalisa untuk proses merupakan data nasabah KOPERIA.

\section{Pengujian Model}

\section{Entropy}

Menghitung nilai total kasus keseluruhan yang ada berdasarkan jumlah kasus yang layak dan tidak layak. Kemudian akan diproses dengan mencari nilai Entropy dari setiap atribut dapat ditunjukan pada rumus (1).

$$
\operatorname{Entropy}(S)=\sum_{i=1}^{n}-p_{i} * \log _{2} p i
$$
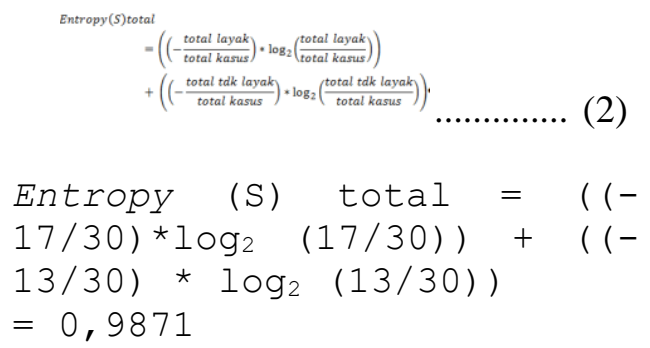

Perhitungan untuk nilai entropy pada setiap himpunan dan atribut, dibawah ini merupakan proses perhitungannya dan Hasil perhitungan dapat dilihat pada table 3 .
Menghitung nilai entropy untuk $\mathrm{S}_{>}$ 5Juta, S3-5Juta $_{\text {untuk Jumlah Penghasilan }}$ antara lain:

$$
\begin{aligned}
& \text { Entropy (> 5Juta) })((- \\
& \left.14 / 25) \star \log _{2}(14 / 25)\right)+((- \\
& \left.11 / 25) * \log _{2}(11 / 25)\right) \\
& =0,468441+0,521147 \\
& =0,9896 \\
& \text { Entropy }(3-5 \text { Juta })=((- \\
& \left.3 / 5) * \log _{2}(3 / 5)\right)+((- \\
& \left.2 / 5) * \log _{2}(2 / 5)\right) \\
& =0,442179+0,528771 \\
& =0,971
\end{aligned}
$$

\section{Information Gain}

Perhitungan niali Gain pada setiap himpunan atribut, dibawah ini proses pergitungannya. Menghitung nilai Gain dapat dilitunjukan pada rumus (3).

$$
\begin{aligned}
& \operatorname{Gain}(\mathrm{S}, \mathrm{A})=\operatorname{Entropy}(S)- \\
& \sum_{i=0}^{n} \frac{|S| \mathrm{S} \mid}{|S|} * \operatorname{Entropy}(S i)
\end{aligned}
$$

Gain ( jumlah penghasilan )

$$
\begin{aligned}
& =0,9871-((25 / 30 * 0,9896)+ \\
& (5 / 30 * 0,971)) \\
& =0,001
\end{aligned}
$$

3. Proses pembuatan pohon

Dari hasil perhitungan pada table 3 dapat di ketahui nilai Gain yang terbesar yaitu 0,473 adalah himpunan Keperluan, maka hasil pohon keputusan sementara dapat dilihat pada gambar 1 .

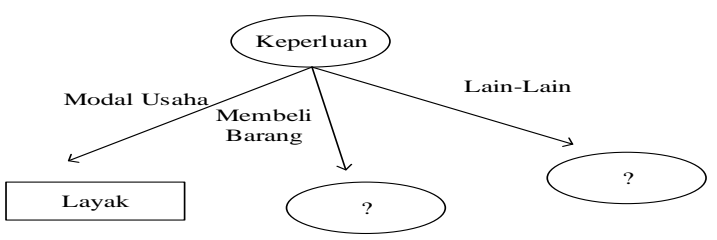

Gambar 1 Pohon keputusan pada node 1

Dengan memperhatikan pohon keputusan pada gambar 2 diketahui bahwasemua kasus sudah masuk dalam kelas, dengan demikian pohon keputusan pada gambar merupakan pohon keputusan terakhir yang terbentuk. Dihasilkan sejumlah aturan dalam pohon tersebut. Berikut ini aturan 
yang dihasilkan pada pohon keputusan akhir sebagai berikut:

"Jika Keperluan Membeli Barang dan Jumlah Pinjaman 11-20 Juta Maka = Tidak Layak"

"Jika Keperluan Membeli Barang dan Jumlah Pinjaman 6-10 Juta Maka = Layak" "Jika Keperluan Membeli Barang dan Jumlah Pinjaman 1-5 Juta Maka = Tidak Layak"

"Jika Keperluan Lain-lain dan Jumlah Penghasilan > 5 Juta Maka = Tidak Layak" "Jika Keperluan Lain-lain dan Jumlah Penghasilan 3-5 Juta dan Jumlah Pinjaman 11-20 Juta Maka = Tidak Layak"

"Jika Keperluan Lain-lain dan Jumlah Penghasilan 3-5 Juta dan Jumlah Pinjaman 6-10 Juta Maka = Tidak Layak".

"Jika Keperluan Lain-lain dan Jumlah Penghasilan 3-5 Juta dan Jumlah Pinjaman 1-5 Juta Maka = "Layak".

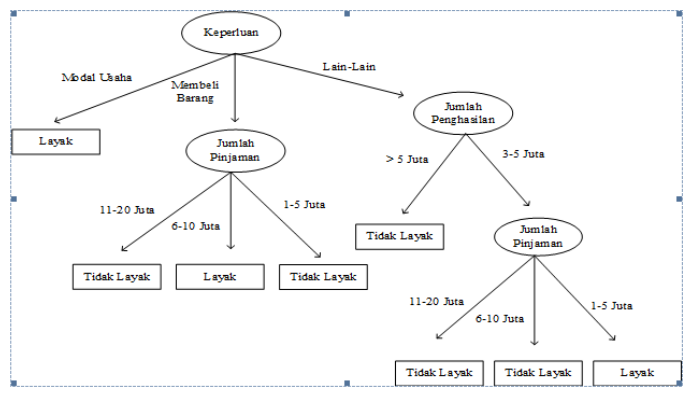

Gambar 2. Pohon Keputusan Akhir Gambar 2. Pohon Keputusan Akhir

Hasil klasifikasi pada data sampling atribut keperluan sebagai root pada decision tree,sedangkan atribut lainnya sebagai child node. Dari data sampling 30 record dihasilkan jumlah aturan yang terbentuk sebanyak 7 aturan.

Tahap selanjutnya proses pengolahan data dari hasil yang diperoleh dari konsep algoritma C4.5. sebelum di proses dengan aplikasi WEKA data di pecah menjadi 2 bagian, yaitu pertama sebagai data training sebanyak $75 \%$ data testing sebanyak 35\% hal ini supaya dapat terbentuk model dengan menggunakan data training, selanjutnya data yang terbentuk akan diujikan kembali menggunakan data testing.
Table 3 Nilai Perhitungan Entropy dan Gain

\begin{tabular}{|c|c|c|c|c|c|c|}
\hline $\begin{array}{l}\text { Atribu } \\
\text { t }\end{array}$ & $\begin{array}{l}\text { Katego } \\
\text { ri }\end{array}$ & $\begin{array}{c}\text { Banya } \\
k \\
\text { Kasus } \\
\end{array}$ & Layak & $\begin{array}{l}\text { Tidak } \\
\text { Layak }\end{array}$ & $\begin{array}{c}\text { Ent } \\
\text { rop } \\
y\end{array}$ & $\begin{array}{l}\text { Gai } \\
n\end{array}$ \\
\hline $\begin{array}{l}\text { Total } \\
\text { kasus }\end{array}$ & & 30 & 17 & 13 & $\begin{array}{c}0,98 \\
71\end{array}$ & \\
\hline \multirow{3}{*}{$\begin{array}{l}\text { Jml } \\
\text { Pengh } \\
\text { asilan } \\
\end{array}$} & & & & & & $\begin{array}{l}0,0 \\
01\end{array}$ \\
\hline & $\begin{array}{ll}> & 5 \\
\text { Juta }\end{array}$ & 25 & 14 & 11 & $\begin{array}{c}0,98 \\
96\end{array}$ & \\
\hline & $\begin{array}{l}3-5 \\
\text { Juta }\end{array}$ & 5 & 3 & 2 & $\begin{array}{c}0,97 \\
1\end{array}$ & \\
\hline \multirow[t]{4}{*}{\begin{tabular}{|l|l} 
Jml \\
Saldo \\
\end{tabular}} & & & & & & $\begin{array}{c}0,1 \\
1\end{array}$ \\
\hline & ${ }_{\text {juta }} 3$ & 5 & 4 & 1 & $\begin{array}{c}0,72 \\
19\end{array}$ & \\
\hline & & 23 & 13 & 10 & $\begin{array}{c}0,98 \\
77\end{array}$ & \\
\hline & $\begin{array}{ll}< & 1 \\
\text { Juta } & \end{array}$ & 2 & 0 & 2 & 0 & \\
\hline \multirow[t]{4}{*}{$\begin{array}{l}\text { Jml } \\
\text { Pinja } \\
\text { man } \\
\end{array}$} & & & & & & $\begin{array}{c}0,3 \\
18\end{array}$ \\
\hline & $\begin{array}{l}11-20 \\
\text { Juta }\end{array}$ & 4 & 4 & 0 & 0 & \\
\hline & $\begin{array}{l}\text { 6-10 } \\
\text { Juta }\end{array}$ & 15 & 11 & 4 & $\begin{array}{c}0,83 \\
66\end{array}$ & \\
\hline & $\begin{array}{l}1-5 \\
\text { Juta }\end{array}$ & 11 & 2 & 9 & $\begin{array}{c}0,68 \\
4\end{array}$ & \\
\hline \multirow[t]{4}{*}{$\begin{array}{l}\text { Jangk } \\
\mathrm{a} \\
\text { Wakt } \\
\mathrm{u} \\
\end{array}$} & & & & & & $\begin{array}{l}0,1 \\
89\end{array}$ \\
\hline & $\begin{array}{l}1-4 \\
\text { Bulan }\end{array}$ & 1 & 1 & 0 & 0 & \\
\hline & $\begin{array}{l}5-8 \\
\text { Bulan }\end{array}$ & 20 & 8 & 12 & $\begin{array}{c}0,97 \\
1\end{array}$ & \\
\hline & $\begin{array}{l}9-12 \\
\text { Bulan }\end{array}$ & 9 & 8 & 1 & $\begin{array}{c}0,50 \\
33\end{array}$ & \\
\hline \multirow[t]{4}{*}{$\begin{array}{l}\text { Keper } \\
\text { luan }\end{array}$} & & & & & & $\begin{array}{l}0,4 \\
73\end{array}$ \\
\hline & $\begin{array}{l}\text { Modal } \\
\text { Usaha }\end{array}$ & 10 & 10 & 0 & 0 & \\
\hline & $\begin{array}{l}\text { Memb } \\
\text { eli } \\
\text { Barang }\end{array}$ & 8 & 5 & 3 & $\begin{array}{c}0,95 \\
44\end{array}$ & \\
\hline & $\begin{array}{l}\text { Lain- } \\
\text { lain }\end{array}$ & 12 & 2 & 10 & $\begin{array}{c}0,65 \\
0\end{array}$ & \\
\hline
\end{tabular}

Hasil klasifikasi data training sebanyak $65 \%$ dengan menggunakan WEKA dapat dilihap pada gambar 3.

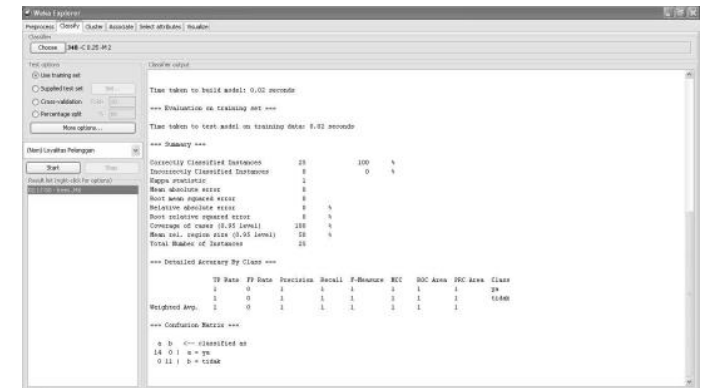

Gambar 3. Hasil Klasifikasi data Training Set menggunakan WEKA.

Pada saat menggunakan data training dengan menggunakan WEKA 3.7.7 waktu yang dibutuhkan untuk menguji 
model pada training ini adalah 0.02 second dalam mengklasifikasikan diaplikasi weka 3.7.7. dari confusion matrix dapat dilihat ada 13 rekords data diklasifikasikan sebagai class YA, 10 rekords data yang diklasifikasikan sebagai class TIDAK dan 2 record diklasifikasikan kedalam class yang tidak sesuai yaitu data diduga sebagai class YA ternyata adalah class TIDAK. Hasil akurasi detail dapat dilihat pada gambar 4 .

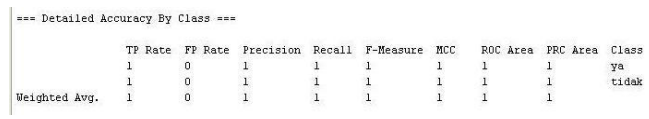

\section{Gambar 4. Hasil Akurasi Detail oleh Class Training}

Tingkat positif benar (TP) Rate adalah proporsi contoh yang diklasifikasikan sebagai kelas $\mathrm{x}$, diantara semua contoh yang benar-benar memiliki kelas $\mathrm{x}$ yang bernilai sama dengan recall.

Untuk mencari nilai TP rate pada class YA, pada rumus 4:

Positive predictive value $=\frac{14}{14+0}=1$

Untuk mencari nilai FN sama pada class Tidak ,pada rumus 5:

False Negatif $=\frac{11}{11+0}=1$ (5)

Tingkat positif salah (FP) rate adalah proporsi yang diklasifikasikan sebagai kelas $\mathrm{x}$, tetapi masuk kedalam kelas yang berbeda diantara semua contoh yang bukan dari kelas $\mathrm{x}$.

Untuk mencari nilai FP sama pada class Ya, berikut rumusnya (6) :

False Positive $=\frac{0}{0+14}=0$ (6)

Untuk mencari nilai FN sama pada class Tidak, berikut rumusnya (7):

False Negative $=\frac{0}{0+11}=0(7)$

Untuk mencari precision class YA, berikut rumusnya (8):

$\frac{14}{14+0}=1$ (8)
Proses selanjutnya yaitu klasifikasi menggunakan data testing sebanyak 35\% dengan menggunakan weka. Hasil klasifikasi menggunakan data testing pada gambar 5.

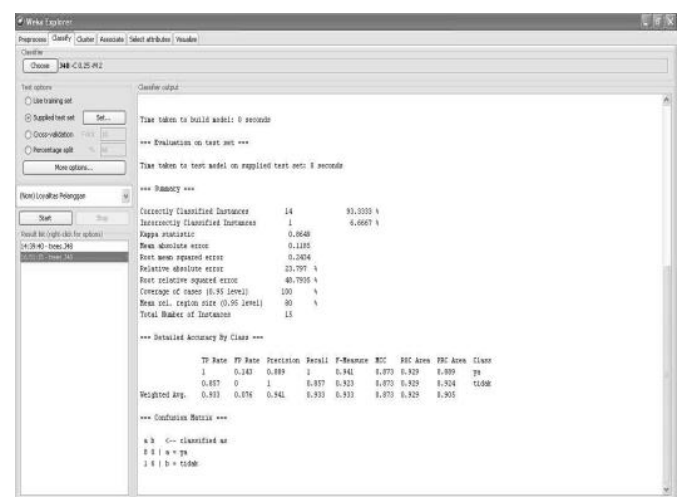

Gambar 5. Hasil Klasifikasi data testing

Waktu yang dibituhkan untuk menguji model training ini 0 second dalam mengklasifikasikan dari confusion matrix dapat dilihat ada 8 rekords data diklasifikasikan sebagai class YA, 6 rekords data yang diklasifikasikan sebagai class TIDAK dan 1 record diklasifikasikan kedalam class yang tidak sesuai yaitu data diduga sebagai class YA ternyata adalah class TIDAK.

Tingkat positif benar (TP) Rate adalah proporsi contoh yang diklasifikasikan sebagai kelas $\mathrm{x}$, diantara semua contoh yang benar-benar memiliki kelas $\mathrm{x}$ yang bernilai sama dengan recall.

Untuk mencari nilai TP rate pada class YA berikut rumusnya (9).

Positive predictiveb value $=\frac{8}{8+0}=1(9)$

Untuk mencari nilai FN sama pada class Tidak berikut rumusnya (10):

False Negative $=\frac{6}{6+8}=0.143(10)$

Tingkat positif salah (FP) rate adalah proporsi yang diklasifikasikan sebagai kelas $\mathrm{x}$, tetapi masuk kedalam kelas yang berbeda diantara semua contoh yang bukan dari kelas $\mathrm{x}$.

Untuk mencari nilai FP sama pada class Ya berikut rumusnya (11): 
false Positive $=\frac{6}{8+1}=0.143(11)$

Untuk mencari nilai FN sama pada class Tidak berikut rumusnya (12):

false Negative $=\frac{o}{o+6}=0(12)$

Untuk mencari precision class YA berikut rumusnya (13).

$\frac{9}{8+1}=0.889$

Untuk mencari precision class Tidak, berikut rumusnya (14).

$\frac{6}{6+0}=1(14)$

F-measure yang merupakan ukuran gabungan dari precision dan recal.proses perhitungannya pada rumus (15).

$F-$ Measure $=\frac{2 * \text { Precision } * \text { recal }}{\text { Precision }+ \text { Recall }}$

Untuk mencari F-Measure classYa pada rumus (16):

$$
\frac{2 * 1 * 0.867}{1 * 0.867}=0.929
$$

Untuk mencari F-measure class TIDAK pada rumus (17).

$$
\begin{aligned}
\frac{2 * 0.833 * 1}{0.833+1} & =0.909 \\
\frac{2 * 0.833 * 1}{0.833+1} & =0.909
\end{aligned}
$$

Tahap selanjutnya mengukur evaluasi untuk mengetahui evaluasi dari kinerja model klasifikasi. Pada weka classifier hasil klasifikasi yang diperoleh akan disertakan dengan beberapa alat ukur sebagai bukti terjadinya hasil proses pada klasifikasi tersebut yang telah tersedia didalamnya, salah satu alat ukur tersebut adalah confusion matrix. Berikut ini adalah hasil kesimpulan confusion matrik yang terdaat pada aplikasi WEKA dari hasil yang diperoleh dari data training, dapat dilihat pada gambar 6.

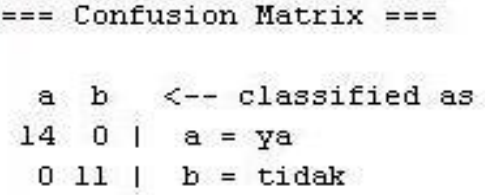

Gambar 6. Hasil Confusion Matrix

Dari informasi tersebut, kemudian akan dilakukan proses perhitungan rata-rata persentasiakurasi keberhasilan dan error rate pada confusion matrix data training dapat ditunjukan pada perhitungan (18).

Akurasi $=\frac{\text { banyaknya prediksi yang benar }}{\text { total banyaknya prediksi }}=\frac{f_{11}+f_{00}}{f_{11}+f_{10}+f_{01}+f_{00}}$

Error Rate $=\frac{\text { banyaknya prediksi yang salah }}{\text { total banyaknya prediksi yang salah }}=\frac{f_{10}+f_{01}}{f_{11}+f_{10}+f_{01}+f_{00}}$

Akurasi $=\frac{14+11}{14+0+0+11}=1$

Persentase Akurasi $=1 \mathrm{x} 100 \%=100 \%$

Error Rate $=\frac{0+0}{14+0+0+11}=0$

Persentase Error $=0 \times 100 \%=0 \%$

Proses selanjutnya adalah hasil kesimpulan confusion matrix yang terdapat pada aplikasi WEKA dari hasil yang diperoleh menggunakan data nasabah yang diambil merupakan data testing dapat dilihat pada gambar 7.

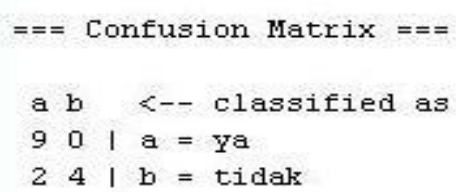

Gambar 7. Hasil confusion matrix data testing

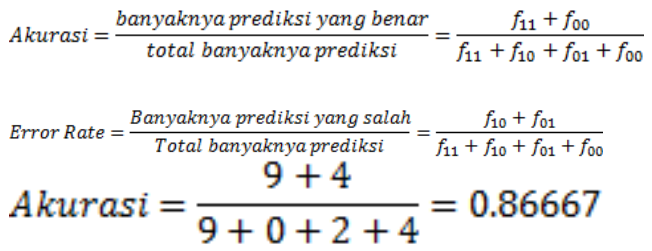


Persentase Akurasi $=0.86667 \times 100 \%=$ $86.67 \%$

Error Rate $=\frac{0+2}{9+0+2+4}=0.1333$

Persentase Error rate $=0.1333 \times 100 \%=$ $13.33 \%$

Dari hasil rata-rata data training dan testing dapat dilihat pada tabel 4.

Tabel 4. Hasil Akurasi dan error rate

\begin{tabular}{|c|c|c|}
\hline Dataset & $\begin{array}{c}\text { Akurasi } \\
(\%)\end{array}$ & $\begin{array}{c}\text { Error Rate } \\
(\%)\end{array}$ \\
\hline Data training & $100 \%$ & $0 \%$ \\
\hline
\end{tabular}

Berdasarkan pada table 4 dapat dilihat nilai akurasi data training serta data testing menggunakan algoritma $\mathrm{C} 4.5$, kedua proses tersebut rata-rata $93 \%$, dan error rate $6.6 \%$. Hal ini membuktikan bahwa algoritma C4.5 dapat digunakan untuk proses penentuan kelayakan kredit.

a. Implementasi

Pada penelitian ini hasil proses dengan menggunakan algoritma C4.5, akan di implementasikan kedalam sebuah software untuk proses dalam menentukan kelayakan kedit pada KOPERIA. Dapat dilihat pada gambar 8 $-11$.

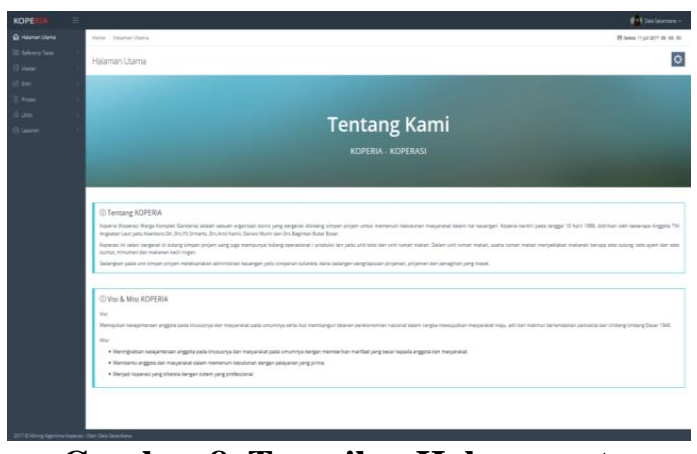

Gambar 8. Tampilan Halaman utama

Halaman utama aplikasi data mining untuk penentuan kelayakan kredit pada KOPERIA Tampilan proses intput data nasabah yang akan melakukan pengajuan kredit, input data pengajuan kredit nasabah berdasarkan himpunan attribut algoritma $\mathrm{C} 4.5$ yang sudah diproses perhitungan sebelumnya sebelum di Implementasikan ke software.
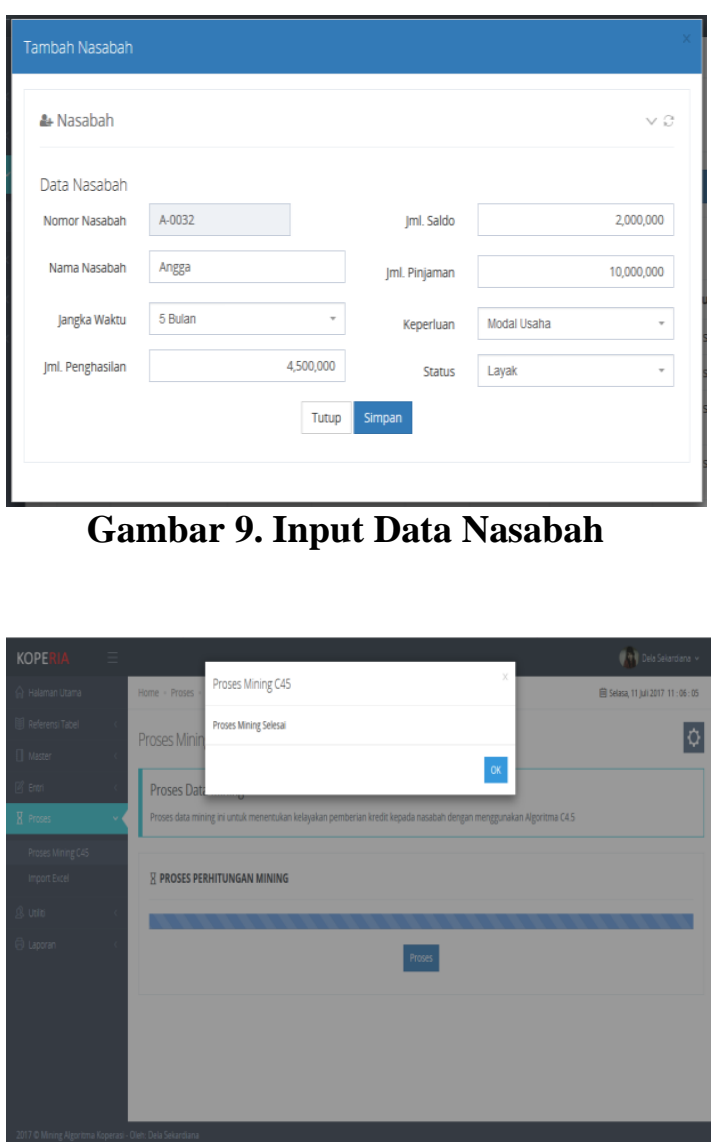

Gambar 10.Proses Mining Algoritma

C4.5

Tampilan proses penerapan data mining algoritma C4.5 dalam menentukan kelayakan nasabah yang akan mengajukan kredit

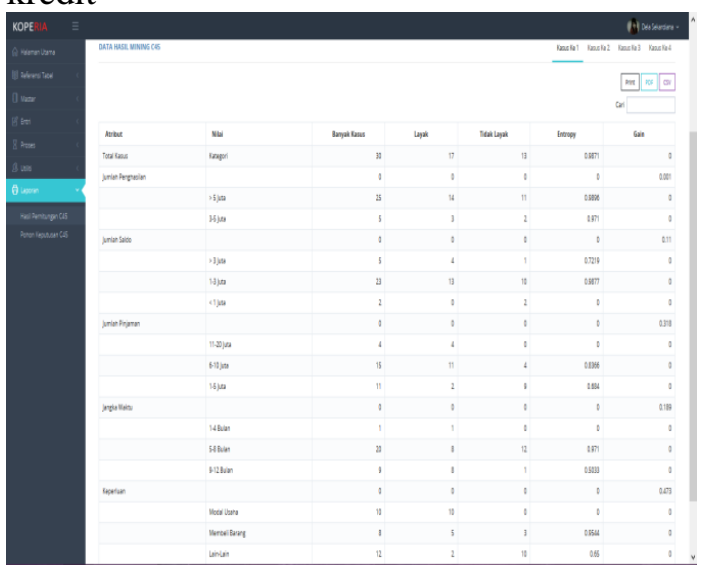

Gambar 11. Tampilan Implementasi Data Hasil 
Tampilan hasil data keseluruhan yang sudah di proses dengan Algoritma C4.5, yang nantinya sudah menjadi keputusan dalam penentuan kelayakan kredit.

\section{KESIMPULAN}

Berdasarkan analisa penggunaan data mining dengan algoritma C4.5 terbukti akurat dalam penentuan pengajuan kelayakan kredit. Hal ini dibuktikan dengan hasil evaluasi penenelitian bahwa algoritma C4.5 mendapatkan nilai akurasi data training serta data testing menggunakan algoritma $\mathrm{C} 4.5$, kedua proses tersebut ratarata $93 \%$, dan error rate $6.6 \%$

\section{DAFTAR PUSTAKA}

[1] Andi. (2016). Pemrograman PHP dan MySQL. . Yogyakarta: MADCOMS.

[2] Firmansyah. (2011). Penerapan Algoritma Klasifikasi C4.5 Untuk Penentuan Kelayakan Pemberian Kredit Koperasi. Jakarta: STMIK Nusa Mandiri.

[3] Haryati, Siska, Sudarsono, A., \& Suryana, E. (2015). Implementasi Data Mining Untuk Memprediksi Masa Studi Mahasiswa Menggunakan Algoritma C4.5 (Studi Kasus:
Universitas Dehasen Bengkulu). Jurnal Media Infotama.

[4] Kusrini , E. T. (2009). Algoritma Data Mining. Yogyakarta: CV Andi Offset.

[5] Larose, D.T. (2005). Discovering Knowledge in Data.

[6] Masripah, S. (2015). Evaluasi Penentuan Kelayakan Pemberian Kredit Koperasi Syariah Menggunakan Algoritma Klasifikasi C4.5. Jurnal Pilar Nusa Mandiri, XI.

[7] Munawar. (2005). Pemodelan Visual Dengan UML. Yogyakarta: Graha Ilmu.

[8] Rusito, M. T. (2016). Implementasi Metode Decision Tree Dan Algoritma C4.5 Untuk Klasifikasi Data Nasabah Bank. Infokam, Vol.1.

[9] Santoso, T. B. (2014). Analisa dan Penerapan Metode C4.5 untuk Prediksi Loyalitas Pelanggan. Jurnal Ilmiah Fakultas Teknik - LIMIT'S Vol.10 (1) Hal.22-31. 